\title{
N-Glycosylthioureido Aglyco-ristocetins without Platelet Aggregation Activity
}

\author{
Ferenc Sztaricskai, Gábor Pintér, Erzsébet Röth, Pál Herczegh, Szilvia Kardos, \\ Ferenc Rozgonyi, Zoltán Boda
}

Received: June 7, 2007 / Accepted: July 26, 2007

(C) Japan Antibiotics Research Association

\begin{abstract}
The water-soluble $N$-methoxy-PEG-yl-, $N$ - $\beta$-Dglucopyranosyl- and $N$ - $\beta$-D-maltosylthioureido aglycoristocetin were prepared which, in contrast to ristocetin A, did not induce thrombocyte aggregation. The antibacterial activity of $N$ - $\beta$-D-maltosylthioureido aglyco-ristocetin A against MRSA was comparable to that of ristocetin A, while its activity against Enterococcus faecalis (VRE, TSE) is somewhat stronger when compared to those of vancomycin and ristocetin $\mathrm{A}$.
\end{abstract}

Keywords glycopeptide antibiotics, platelet aggregation, synthesis, antibacterial activity

\section{Introduction}

Ristocetin A (1) was discovered by American researchers [1] fifty years ago, but its glycopeptide structure was elucidated much later [2]. Similarly to vancomycin and teicoplanin, $\mathbf{1}$ is also effective against MRSA [3], but causes thrombocytopenia [4] making the antibiotic inapplicable for therapeutic purposes. However, it was shown later that in the blood of patients suffering from von Willebrand's disease $\mathbf{1}$ does not induce thrombocyte aggregation [5,6]. As a result, $\mathbf{1}$ is now used as a routine laboratory agent to diagnose von Willebrand's disease. Further studies [7, 8] on the glycopeptide antibiotics revealed that vancomycin and actinoidin, possessing similar structure, do not exhibit platelet aggregation, consequently the mechanism of the effect of the latter two antibiotics on thrombocytes must be different from that of $\mathbf{1}$.

Structure-activity relationship studies have shown that the $\alpha$-L-rhamnopyranosyl moiety of the heterotetrasaccharide side-chain [9] and the $C$-terminal methoxycarbonyl and phenolic hydroxyl groups of the heptapeptide aglycone [7] can be responsible for the agglutination effect of $\mathbf{1}$. In contrast, no effect of the free amino groups on the platelet aggregation properties was observed [7]. The above structural elements facilitate the binding of the antibiotic to specific sequences of von Willebrand's factor (vWF) thereby inducing the interaction of vWF with platelet glycoprotein 1b (GP1b) and initiating aggregation [10]. The dimerization ability of $\mathbf{1}$ may also play an important role in this mechanism $[9,11]$.

Despite its significant antibacterial effect (Table 1), due to the above-mentioned undesired haematological complications 1 was not put into clinical practice.

The goal of our present work was to synthesize ristocetin derivatives that retain the antibacterial activity but do not induce platelet aggregation.

\section{Results and Discussion}

The glycopeptide antibiotics exert biological activity by developing hydrogen bondings between the glycopeptide aglycones and the L-Lys-D-Ala-D-Ala terminal monomer fragment of the peptidoglycan located in the bacterial
F. Sztaricskai (Corresponding author), G. Pintér, E. Röth, P. Herczegh: Department of Pharmaceutial Chemistry, University of Debrecen, H-4010 Debrecen, P.O.Box 70, Hungary,

E-mail: sztarife@delfin.klte.hu
S. Kardos, F. Rozgonyi: Institute of Medicinal Microbiology, Semmelweis University, H-1445 Budapest, P.O.Box 370, Hungary Z. Boda: IInd Department of Medicine, University of Debrecen, H-4012 Debrecen, P.O.Box 58, Hungary 
Table 1 Comparison of the antibacterial effects of the new antibiotic analogs

\begin{tabular}{|c|c|c|c|c|c|c|c|c|}
\hline \multirow{4}{*}{ Test microorganisms } & \multicolumn{8}{|c|}{$\mathrm{MIC} \mu \mathrm{g} / \mathrm{ml}$} \\
\hline & \multirow{3}{*}{$\begin{array}{l}\text { Ristocetin A } \\
\text { (1) }\end{array}$} & \multirow{3}{*}{$\begin{array}{l}\text { Aglyco- } \\
\text { ristocetin } \\
\text { (2) }\end{array}$} & $\begin{array}{l}\text { N-metoxy- } \\
\text { PEG-yl }\end{array}$ & $\begin{array}{c}N-\beta \text {-D- } \\
\text { gluco- } \\
\text { pyranosyl }\end{array}$ & $\begin{array}{l}N-\beta \text {-D- } \\
\text { maltosyl }\end{array}$ & \multirow{3}{*}{$\begin{array}{l}\text { Vanco- } \\
\text { mycin }\end{array}$} & \multirow{3}{*}{ Teicoplanin } & \multirow{3}{*}{ Linezolid } \\
\hline & & & \multicolumn{3}{|c|}{ Thioureido aglyco-ristocetin } & & & \\
\hline & & & (4) & $(6)$ & (8) & & & \\
\hline $\begin{array}{l}\text { Enterococcus faecalis ATCC } \\
51299 \text { (VRE, TSE) }\end{array}$ & 16 & 4 & ND & 16 & 8 & 32 & 1 & 3 \\
\hline $\begin{array}{l}\text { Enterococcus faecalis ATCC } \\
29212 \text { (VSE, TSE) }\end{array}$ & 2 & 4 & ND & 16 & 8 & 0.5 & 0.5 & 4 \\
\hline $\begin{array}{l}\text { Staphylococcus aureus ATCC } \\
29213 \text { (MSSA) }\end{array}$ & 1 & 2 & 32 & 8 & 2 & 0.5 & 0.5 & 2 \\
\hline $\begin{array}{l}\text { Staphylococcus aureus ATCC } \\
33591 \text { (MRSA) }\end{array}$ & 4 & 2 & 32 & 8 & 4 & 1 & 0.5 & 1.5 \\
\hline $\begin{array}{l}\text { Staphylococcus epidermidis } \\
\text { (MRSE) }\end{array}$ & 2 & 2 & 128 & 8 & 4 & 4 & 4 & 1 \\
\hline Bacillus subtilis ATCC 6633 & 0.5 & 2 & 128 & 8 & 4 & 2 & 0.5 & 1 \\
\hline
\end{tabular}

ATCC: American Type Culture Collection; VRE, TSE: Vancomycin resistant, Teicoplanin sensitive van B gene positive; VSE, TSE: Vancomycin sensitive, Teicoplanin sensitive; MSSA: Methicillin-oxacillin sensitive; MRSA: Methicillin-oxacillin resistant, mec A gene positive; MRSE: Methicillinoxacillin resistant, mec $\mathrm{A}$ gene positive.

cell wall. This non-covalent interaction inhibits the transglycosidation and transpeptidation processes and this finally leads to termination of the cell-wall synthesis and destruction of the bacteria.

Our studies have shown that aglyco-ristocetin (2), prepared (Scheme 1) by means of deglycosylation [12] of $\mathbf{1}$, retains the antibacterial activity (Table 1) and this effect is comparable [13] to that of vancomycin, teicoplanin and linezolid used in clinical practice. However, $\mathbf{2}$ is not suitable for thrombocyte-aggregation tests due to its extremely limited solubility in water. To enhance water-solubility, 2 was first reacted with methoxypolyethyleneglycol isothiocyanate (3) to furnish N-PEG-yl-thioureido aglycoristocetin A (4) which was precipitated with ether and purified by column chromatography.

The influence of the presence or absence and the mode of attachment of the particular carbohydrate moieties in the antibiotic molecules on the antimicrobial activity and on the interaction with vWF are not fully demonstrated. Deglycosylation of $\mathbf{1}$ leads not only to the loss of the rhamnose unit, but to the removal of all of the $O$-glycosidic bonds. Substitution of the $N$-terminal primary amino group of 2 allows the synthesis of $N$-glycosyl thioureido derivatives. For this purpose 2 was treated with 2,3,4,6- tetra- $O$-acetyl-D-glucopyranosyl isothiocyanate (5) and after chromatographic purification the partially acetylated derivative (6a) of the target compound was isolated with 59\% yield (Scheme 1). Zemplén trans-esterification [14] then afforded $N$ - $\beta$-D-glucopyranosylthioureido aglycoristocetin $\mathrm{A}$ (6). An analogous reaction of $\mathbf{2}$ and $2,3,6,2^{\prime}, 3^{\prime}, 4^{\prime}, 6^{\prime}$-hepta- $O$-acetyl-D-maltosyl isothiocyanate (7) and subsequent $O$-deacetylation gave $N$ - $\beta$-Dmaltosylthioureido aglyco-ristocetin A (8). The aglycoristocetin derivatives 4,6 and 8 possessed water-solubility sufficient for studying both the antibacterial effect and the thrombocyte aggregation properties.

Comparison of the antimicrobial activities of the thioureido derivatives with 2 showed that introduction of the $N$-methoxy-PEG-yl group to the molecule resulted in a dramatical decrease in the antibiotic activity of $\mathbf{4}$, which can not be completely explained by the more than doubled molecular mass. At the same time, the activity of the $N-\beta$ D-glucopyranosylthioureido derivative $\mathbf{6}$ was reduced only to one-fourth, and extension of the side chain with the $N-\beta$ D-maltosyl group 8 led to a significant increase in the efficacy. 8 possesses a moderate, but definitive antibacterial activity, its activity against VRE and TSE is higher than those of vancomycin and $\mathbf{1}$ and as active towards MRSA as 


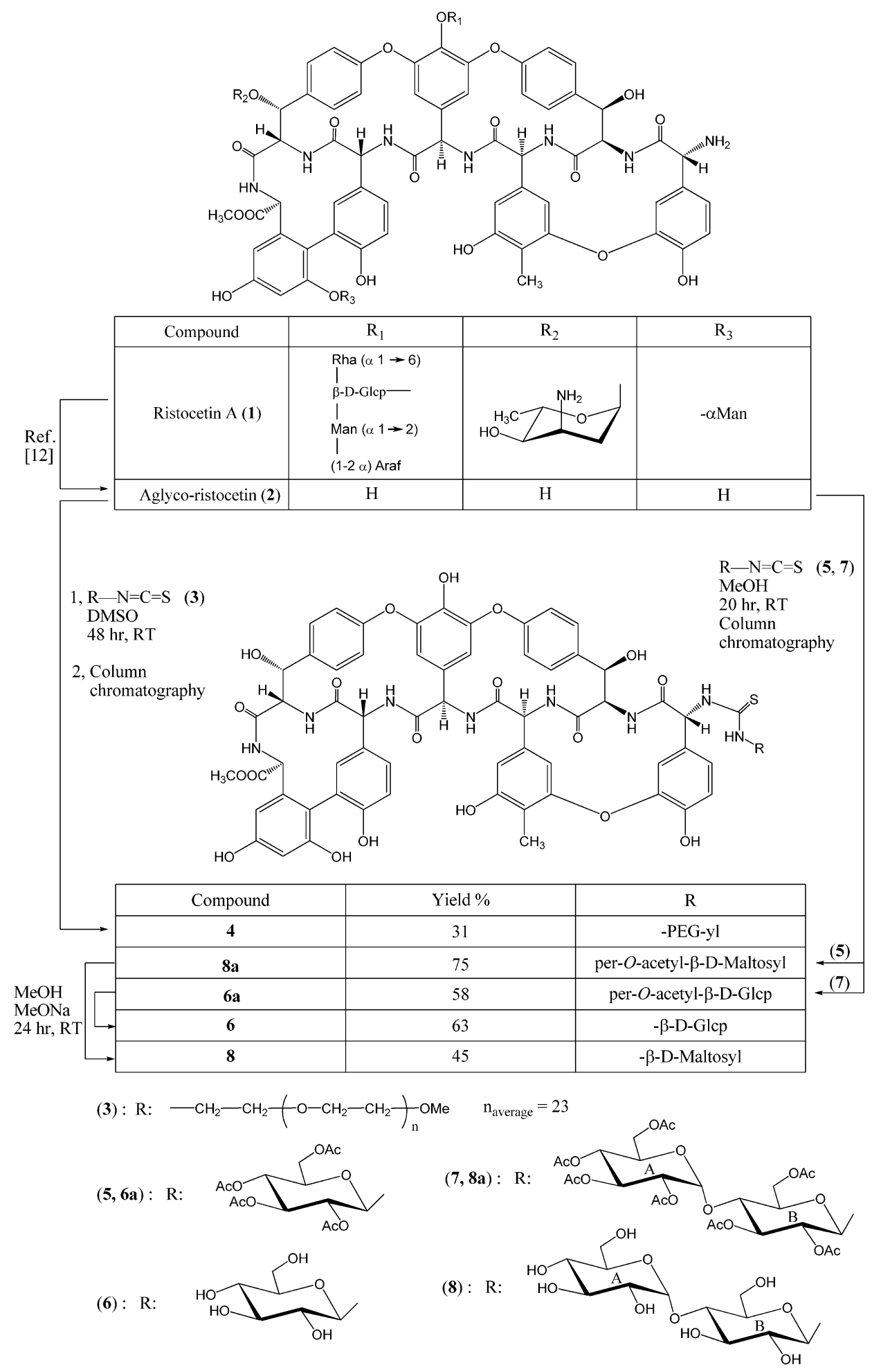

Scheme 1 Syntheses of $\mathrm{N}$-substituted-thioureido aglyco-ristocetin derivatives.

the parent antibiotic 1 .

The enhanced solubility of the prepared new $N$ substituted thioureido aglyco-ristocetin derivatives in water and in the tris-buffer $(\mathrm{pH} \sim 7.4)$ allowed to study their platelet aggregation properties. In contrast to 1 (Aggristin$\mathrm{Kit}^{\circledR}$ [15]) used as control, neither of $\mathbf{4}, \mathbf{6}$ and $\mathbf{8}$ induced aggregation of human thrombocytes in the concentration range of 0.5 and $1.0 \sim 1.5 \mathrm{mg} / \mathrm{ml}$ (Fig. 1). Aggregation of 


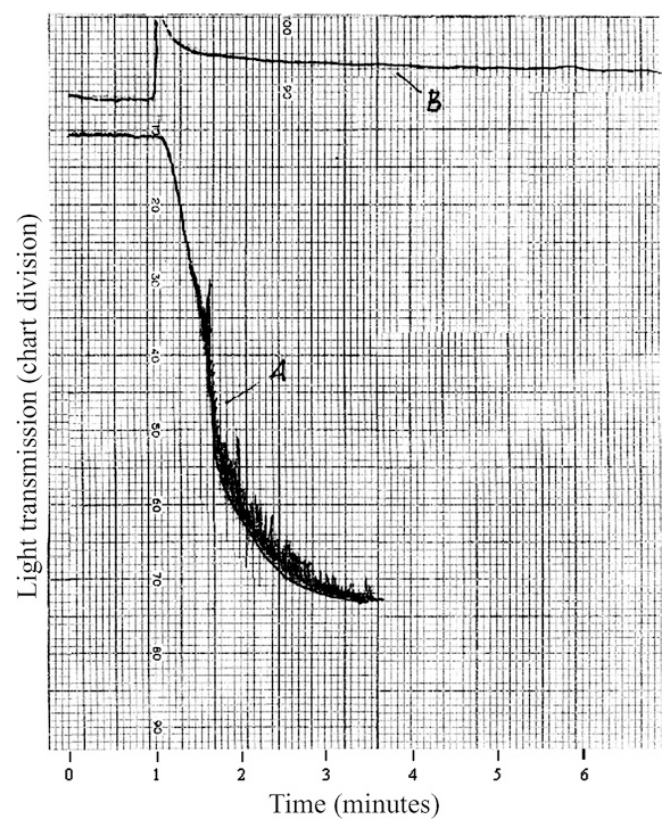

Fig. 1 Investigation of the thrombocyte aggregation properties of ristocetin $A$ (1) and the $N$ - $\beta$-D-maltosyl derivative (8) with a Chrom-Ley Dual Channel Platelet Aggregometer Model 660.

Curve A: $1.5 \mathrm{mg} / \mathrm{ml}$ Aggristin (commercial name of ristocetin A). Curve B: $1.5 \mathrm{mg} / \mathrm{ml}$ of $\mathbf{8}$ added to PRP (platelet rich plasma).

PRP (platelet-rich plasma) in the blood of healthy patients was inhibited by $\mathbf{6}$, but $\mathbf{4}$ and $\mathbf{8}$ did not show such an effect.

These results demonstrate that carbohydrates linked through both $O$-glycosidic and $\mathrm{N}$-glycosidic bonds to the aglycone may also influence thrombocyte aggregation. Although the carbohydrate components of the glycopeptide antibiotics are not involved in the hydrogen bondings between the aglycones and the peptidoglycan of the bacterial cell-wall, but their location and mode of linkage may influence the conformation of the molecule as a whole, and thus development of the so-called binding pocket and occasional dimerization of the molecule. Our findings with $\mathbf{8}$, possessing weak but definitive antibiotic activity and lack of thrombocyte aggreagtion, suggest that further modifications of $\mathbf{2}$ by means of the methods of carbohydrate chemistry may lead to the development of additional valuable basic materials of new drugs.

\section{Experimental}

$\mathbf{2}$ was prepared [12] by the deglycosylation of $\mathbf{1}$, and $\mathbf{3}$ was prepared from the appropriate monomethoxy-amino-PEG by the reaction with thiophosgene [16]. Specific optical rotations were measured with a Perkin-Elmer 341 automatic polarimeter. The solutions were evaporated under diminished pressure at $40^{\circ} \mathrm{C}$. For NMR spectroscopy, a Bruker $2005 \mathrm{Y}$ instrument operating at $200 \mathrm{MHz}$ and $50.3 \mathrm{MHz}$ frequencies, respectively, for the ${ }^{1} \mathrm{H}$ and ${ }^{13} \mathrm{C}$ nuclei was used. Internal TMS was the reference material. The UV spectra were obtained with a Jasco W550 UV-VIS instrument, and the MALDI MS spectra were recorded with a Bruker BIFLEX III mass spectrometer equipped with a TOF analyzer. Thrombocyte aggregation was measured using a Chromo-Ley Dual Channel Platelet Aggregometer, Model 660. For thin layer chromatography Kieselgel 60 $\mathrm{F}_{254}$ (Merck) layer was used and column chromatography was performed on Silicagel $60(0.063 \sim 0.2 \mathrm{~mm}$, Merck) adsorbent and the following developing systems were applied: (A) $\mathrm{CH}_{2} \mathrm{Cl}_{2}-\mathrm{MeOH}(9: 1)$; (B) toluene - $\mathrm{MeOH}$ $(7: 3)$; (C) toluene- $\mathrm{MeOH}(6: 4)$; (D) toluene- $\mathrm{MeOH}$ (1:1); (E) $n-\mathrm{BuOH}-\mathrm{AcOH}-\mathrm{H}_{2} \mathrm{O}(4: 1: 1)$. The spots were visualized in UV light or by spraying with the Pauly reagent. Investigation of the antibacterial activity of the antibiotics and their derivatives was carried out by measuring the MIC values as described earlier [13].

\section{$\mathrm{N}$-Methoxy-PEG-yl-thioureido Aglyco-ristocetin (4)}

To a solution of $2(0.085 \mathrm{mmol})$ in DMSO $(2.0 \mathrm{ml}) \mathbf{3}$ $(0.085 \mathrm{mmol})$ [16] was added and the homogeneous reaction mixture was kept at room temperature for 48 hours. The product 4 was precipitated with dry ether, filtered off, washed with a small volume of ether and the crude product $(170 \mathrm{mg})$ was purified by column chromatography (A) to obtain $30.6 \%$ of pure 4 . TLC: Rf 0.15 (A). UV: $\lambda_{\max } 282 \mathrm{~nm}(\mathrm{MeOH})$. MS (MALDI) $\mathrm{m} / \mathrm{z}$ $2326.2(\mathrm{M}+\mathrm{Na})^{+}$. Calcd. for $\mathrm{C}_{110} \mathrm{H}_{150} \mathrm{O}_{43} \mathrm{~N}_{8} \mathrm{~S} 2302.9$.

\section{$\boldsymbol{N}$ - $\boldsymbol{\beta}$-D-Glucopyranosylthioureido Aglyco-ristocetin (6)}

To a solution of $2(0.2 \mathrm{mmol})$ in methanol $(3.0 \mathrm{ml}) \mathbf{5}$ $(0.22 \mathrm{mmol})$ [17] was added, the reaction mixture was kept at room temperature for 20 hours and then concentrated under diminished pressure. The residue was purified by column chromatography (B) to obtain the acetylated product 6a $(58.3 \%)$. TLC: Rf $0.56(\mathrm{C}) .[\alpha]_{\mathrm{D}}^{25}=-58.4$ (c $0.2, \mathrm{MeOH}) . \mathrm{UV}: \lambda_{\max } 279 \mathrm{~nm}(\mathrm{MeOH}) . \mathrm{MS}$ (MALDI) $m / z 1585.78(\mathrm{M}+\mathrm{Na})^{+}$. Calcd. for $\mathrm{C}_{75} \mathrm{H}_{70} \mathrm{O}_{28} \mathrm{~N}_{8} \mathrm{~S}$ 1563.4.

The $\mathrm{pH}$ of a solution of $\mathbf{6 a}(0.1 \mathrm{mmol})$ in dry methanol $(3.5 \mathrm{ml})$ was adjusted to $\sim 8$ by the addition of $1 \mathrm{M}$ sodium methoxide in methanol and the $O$-deacetylation [14] was monitored by TLC (D) Rf 0.12 . The product 6 (63.3\%), precipitated from the reaction mixture $\left(12\right.$ hours, $\left.20^{\circ} \mathrm{C}\right)$ after concentration under diminished pressure, was filtered off and dried. $[\alpha]_{\mathrm{D}}^{25}=-79.4(c 0.25, \mathrm{MeOH})$. UV: $\lambda_{\max }$ $279 \mathrm{~nm}(\mathrm{MeOH})$. MS (MALDI) $m / z 1417.8(\mathrm{M}+\mathrm{Na})^{+}$. Calcd. for $\mathrm{C}_{67} \mathrm{H}_{62} \mathrm{O}_{24} \mathrm{~N}_{8} \mathrm{~S}$ 1395.3. 
${ }^{1} \mathrm{H}-\mathrm{NMR}$ spectrum (carbohydrate portion, MeOD) $\delta$ ppm: 3.27, 3.40, 3.25, 3.26, 3.33, $3.59\left(\mathrm{H}_{6 \mathrm{a}}, \mathrm{H}_{6 \mathrm{~b}}\right)$.

${ }^{13} \mathrm{C}$-NMR spectrum (carbohydrate portion, MeOD) $\delta$ ppm: 77.7, 77.4, 72.7, 70.1, 77.9, 61.3 (C6).

\section{$\boldsymbol{N}$ - $\boldsymbol{\beta}$-D-Maltosylthioureido Aglyco-ristocetin (8)}

The acetylated product $8 \mathbf{a}$ (75\%) was prepared from $\mathbf{2}$ $(0.06 \mathrm{mmol})$ and $7(0.066 \mathrm{mmol})$ as described above for the preparation of 6. $[\alpha]_{\mathrm{D}}^{25}=-57.3(c 0.11, \mathrm{MeOH})$. UV: $\lambda_{\max }$ $280 \mathrm{~nm}(\mathrm{MeOH})$. MS (MALDI) $\mathrm{m} / z 1873.8(\mathrm{M}+\mathrm{Na})^{+}$. Calcd. for $\mathrm{C}_{87} \mathrm{H}_{86} \mathrm{O}_{36} \mathrm{~N}_{8} \mathrm{~S} 1851.7$.

Zemplén $O$-deacetylation [13] of 8a furnished the target 8 (45\%). TLC: Rf 0.34 (E). $[\alpha]_{\mathrm{D}}^{25}=-55.0(c 0.1, \mathrm{MeOH})$. UV: $\lambda_{\max } 280 \mathrm{~nm}(\mathrm{MeOH})$. MS (MALDI) $\mathrm{m} / z \quad 1580.1$ $(\mathrm{M}+\mathrm{Na})^{+}$. Calcd. for $\mathrm{C}_{73} \mathrm{H}_{72} \mathrm{O}_{29} \mathrm{~N}_{8} \mathrm{~S}$ 1557.4.

${ }^{1} \mathrm{H}-\mathrm{NMR}$ spectrum (carbohydrate portion, MeOD) $\delta$ ppm: $3.85\left(\mathrm{~A}_{4}, \mathrm{~A}_{5}\right), 3.88\left(\mathrm{~A}_{3}\right), 3.99\left(\mathrm{~A}_{2}\right), 4.02\left(\mathrm{~B}_{4}, \mathrm{~B}_{5}\right), 4.12$ $\left(\mathrm{B}_{2}\right), 4.23\left(\mathrm{~B}_{3}\right), 4.17,4.27\left(\mathrm{~A}_{6}, \mathrm{~B}_{6}\right), 5.76\left(\mathrm{~A}_{1}, \mathrm{~B}_{1}\right)$.

${ }^{13} \mathrm{C}$-NMR spectrum (carbohydrate portion, $\left.\mathrm{MeOD}\right) \delta$ ppm: $61.6\left(\mathrm{~A}_{6}, \mathrm{~B}_{6}\right), 70.5\left(\mathrm{~A}_{4}, \mathrm{~A}_{5}\right), 72.9\left(\mathrm{~A}_{2}\right), 73.0\left(\mathrm{~A}_{3}\right), 73.8$ $\left(\mathrm{B}_{2}\right), 77.0\left(\mathrm{~B}_{5}\right), 77.8\left(\mathrm{~B}_{3}\right), 78.1\left(\mathrm{~B}_{4}\right), 84.5\left(\mathrm{~B}_{1}\right), 100.8\left(\mathrm{~A}_{1}\right)$.

Acknowledgements The authors thank the National Scientific Research Found (Grant No.: OTKA TO46744, TO42512) for financial support, Dr. Gyula Batta (Research Group of Antibiotics of the Hungarian Academy of Sciences) and Dr. Sándor Kéki (Department of Applied Chemistry, University of Debrecen) for recording the NMR and the mass spectra. We are indebted to the Gauze Institute of New Antibiotics (Moscow) for the sample of ristocetin (ristomycin) A.

\section{References}

1. Grundy WE, Sinclair AC, Theriault RJ, Goldstein AW, Rickler CJ, Warren HB, Oliver TI, Sylvester JC. Ristocetin, microbiologic properties. Antibiotics Ann 687-692 (1956-1957)

2. Sztaricskai F, Harris CM, Neszmélyi A, Harris TM. Structural studies of ristocetin A (ristomycin A). Carbohydrate-aglycone linkages. J Am Chem Soc 102: 7093-7099 (1980)

3. Neu HC. The crisis in antibiotic resistance. Science 257: 1064-1073 (1992)

4. Gangarosa EJ, Johnson TR, Ramos HS. Ristocetin induced thrombocytopenia: Site and mechanism of action. Arch Intern Med 105: 83-89 (1960)

5. Howard MA, Firkin BG. Ristocetin a new tool in the investigation of platelet aggregation. Thromb Diathesis Haemorrh 26: 362-369 (1971)
6. Weis HJ, Rogers J, Brand H. Defective ristocetin-induced platelet and its correction by factor VIII. J Clin Invest 52: 2697-2707 (1973)

7. Boda Z, Solum NO, Sztaricskai F, Rák K. Study of platelet agglutination induced by the antibiotics of the vancomycin group: Ristocetin (ristomycin), actinoidin and vancomycin. Thrombos Haemostas 42: 1164-1179 (1980)

8. Boda Z, Solum NO, Sztaricskai F, Rák K. Actinoidin: A new inhibitor of ristocetin (and ristomycin) —induced platelet agglutination. Thrombosis Research 17: 603-610 (1980)

9. Bardsley B, Williams DH, BaglinTP. Cleavage of rhamnose from ristocetin A removes its ability to induce platelet aggregation. Blood Coagulation and Fibrinolysis 9: 241-244 (1998)

10. Berndt MC, Ward CM, Booth WJ, Castaldi PA, Mazurow AV, Andrews RK. Identification of aspartic acid 514 through glutamic acid 542 as glycoprotein 1b IX. complex receptor recognition sequence on von Willebrand factor. Mechanism and modulation of von Willebrand factor by ristocetin and botrocetin. Biochemistry 31: 11144-11151 (1992)

11. Hoylaerts MF, Nuyts K, Peerlinck K, Deckmyn H, Vermylen J. Promotion of binding of von Willebrand factor to platelet glycoprotein $\mathbf{1 b}$ by dimers of ristocetin. Biochem J 306: 453-463 (1995)

12. Wanner J, Tang D, McComas CC, Crowley BM, Jiang W, Moss J, Boger DL. A new improved method for deglycosidation of glycopeptide antibiotics exemplified with vancomycin, ristocetin and ramoplanin. Bioorg Med Chem Lett 13: 1169-1173 (2003)

13. Sztaricskai F, Batta Gy, Herczegh P, Balázs A, Jekö J, Röth E, Szabó PT, Kardos SZ, Rozgonyi F, Boda Z. A new series of glycopeptide antibiotics incorporating squaric acid moiety. Synthesis, structural and antibacterial studies. J Antibiot 59: 564-582 (2006)

14. Zemplén G, Gerecs Á, Hadácsi I. Saponification of acetylated carbohydrates (in German). Chem Ber 69: 1827-1830 (1936)

15. Boda Z, Sztaricskai F, Bognár R, Rák K, Zajka G, Daróczy I. Method for preparation of ristomycin (ristocetin) $A$ in high quality and its reagent to the study of platelet agglutination experiments. (in Hungarian) 3020/82 Hungarian Patent (June 28, 1984)

16. Mongondry P, Bonnans-Plaisance C, Jean M, Tassin JF. Mild synthesis of amino-poly(ethylene glycol)s. Application to steric stabilization of clays. Macromolecular Rapid Commun 24: 1091-1100 (2003)

17. Hunsen M, Long DA, D'Ardenne CR, Smith AL. Mild onepot preparation of glycosyl bromides. Carbohydrate Research 340: 2670-2674 (2005)

Kühne M, Györgydeák Z, Lindhorst TK. A simple method for the preparation of glycosyl isothiocyanates. Synthesis 6 : 949-951 (2006) 